\title{
Keynes's German contenders 1932-1944: on the sociology of multiple discoveries in economics
}

Citation for published version (APA):

Backhaus, J. G. (1997). Keynes's German contenders 1932-1944: on the sociology of multiple discoveries in economics. METEOR, Maastricht University School of Business and Economics. METEOR Research Memorandum No. 037 https://doi.org/10.26481/umamet.1997037

Document status and date:

Published: 01/01/1997

DOI:

10.26481/umamet.1997037

Document Version:

Publisher's PDF, also known as Version of record

\section{Please check the document version of this publication:}

- A submitted manuscript is the version of the article upon submission and before peer-review. There can be important differences between the submitted version and the official published version of record.

People interested in the research are advised to contact the author for the final version of the publication, or visit the DOI to the publisher's website.

- The final author version and the galley proof are versions of the publication after peer review.

- The final published version features the final layout of the paper including the volume, issue and page numbers.

Link to publication

\footnotetext{
General rights rights.

- You may freely distribute the URL identifying the publication in the public portal. please follow below link for the End User Agreement:

www.umlib.nl/taverne-license

Take down policy

If you believe that this document breaches copyright please contact us at:

repository@maastrichtuniversity.nl

providing details and we will investigate your claim.
}

Copyright and moral rights for the publications made accessible in the public portal are retained by the authors and/or other copyright owners and it is a condition of accessing publications that users recognise and abide by the legal requirements associated with these

- Users may download and print one copy of any publication from the public portal for the purpose of private study or research.

- You may not further distribute the material or use it for any profit-making activity or commercial gain

If the publication is distributed under the terms of Article $25 \mathrm{fa}$ of the Dutch Copyright Act, indicated by the "Taverne" license above, 
Revised 18 July, 1997

Keynes's German Contenders 1932-1944: On the Sociology of Multiple Discoveries in Economics

To be published in History of Economic Ideas

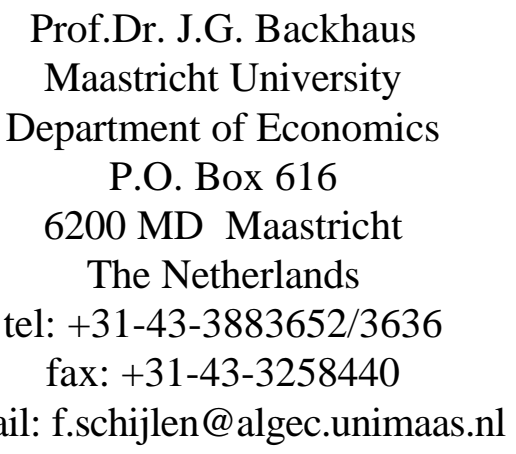

J.E.L. code: B22, B49, H19, N14 
Keynes's German Contenders 1932-1944

On the Sociology of Multiple Discoveries in Economics

\begin{abstract}
In a pathbreaking study on some alleged anticipations of Keynes's General Theory of Employment, Interest and Money, Don Patinkin in apparently applying Merton's sociological approach to the problem of anticipations and multiples in economics, rejects Kalecki and the Stockholm School as anticipators.

Patinkin's contribution has a dual significance in improving our understanding of Keynesian economics, on the one hand, and in suggesting a novel approach to the sociology of economics on the other. This paper is concerned with Patinkin's sociology. His approach by emphasizing the "central message" of a particular work, neglects the received sociological theory of knowledge in a way that compromises his entire investigation. This contention is illustrated by looking at Keynes's German contenders. They had anticipated Keynesian theories and applied them in the years before the General Theory was published. Nevertheless, they rejected aspects of Keynesian economics after the appearanced the General Theory. True to his narrowly focussed approach, Patinkin could not analyze this body of work, which both anticipated and extended the General Theory. Keynes's central message significantly differed from that of his contenders.
\end{abstract}

Acknowledgement: This paper was given at various occasions and I have benefitted from many comments. In particular, I should like to thank Gary Anderson, Philip Davis, and Terence Hutchison. 
On the Sociology of Multiple Discoveries in Economics.

In a pathbreaking study on some alleged anticipations of Keynes's General Theory of Employment, Interest, and Money (Keynes 1936), Don Patinkin some time ago attempted an application of Merton's sociological approach (Merton 1961) to the problem of anticipations an multiples in economics. He relied on the case study method and examined the contributions of Michal Kalecki (Kalecki 1979) and the Stockholm School (notably Ohlin 1981). Both had claimed to have anticipated Keynes' General Theory. Patinkin rejected their claim after demonstrating that the central message of Keynes was not the central message of either Kalecki or the Stockholm School.

Patinkin's contribution has a dual significance. On the one hand, he has much improved our understanding of Keynesian economics in its various elements (Backhaus 1986); on the other hand, he used a novel approach to the sociology of economics (Patinkin 1983). This point is worth making, since an inadvertent reader may assume from the many references to Merton that Patinkin simply applies Merton to economics. That is emphatically not the case. Patinkin's method is unique and deserves a serious discussion. Whereas Merton pioneered in the sociology of knowledge, Patinkin presents us with a new approach to the economic sociology of knowledge and applied to economics, as it happens. ${ }^{1}$

This essay is concerned with the latter, i.e. the sociological aspect. The paper is divided into three parts. I start by reviewing Patinkin's contribution in the context of earlier studies on multiple discoveries. Although I generally agree with him on the substantive economic issues involved, his approach neglects the sociological theory of knowledge in a way that compromises his entire investigation. Hence, I will emphasize those aspects that correspond to the social institutions in which economic research takes place. On this basis I have derived a research agenda that significantly differs from Patinkin's. Second, I illustrate this approach by drawing on a different case, Keynes's German contenders. They had anticipated Keynesian theories and applied them before the General Theory had appeared. True to his new approach for studying multiple discoveries, Patinkin is forced to ignore this body of work, which both anticipated and extended the General Theory. The reason is clear: Keynes's central message was not the central message of his contenders. Third, I note several conclusions.

Before beginning my presentation, I must issue a warning. I want to limit myself strictly to drawing attention to Patinkin's method and to showing that, in some cases, it is inappropriate for his stated purposes. In support, I cite the case of Keynes's German contenders, because Patinkin demonstrated his method in a case study of Keynes. But in this essay I cannot document or carefully interpret the contributions of the German contenders I refer to. Although drawing on published work by others and myself, I am not reproducing it at this point. Likewise, I restrict myself to published sources, eliminating references to archival or other material that is not in the public domain. Finally, by referring to the specific case of Keynes's German contenders I do not want to claim any particular significance for their work not shared by other forerunners in Warsaw, Stockholm, Chicago, or elsewhere. From the point of view of Patinkin's sociological research, however, they provide an excellent counterexample. 
From a sociological point of view, the Keynesian revolution in economics remains a puzzle. Keynesianism's central paradigm has never been completely accepted by the economics profession, nor has its underlying vision (Schumpeter 1954;V.5) become the standard of the professional economist. Likewise, its conception of the State's functions in the economy (see Keynes 1936, chapter 14$)^{2}$ is accepted by only a few in the economics profession. Since the advent (and current demise) of Keynesianism cannot be explained solely in terms of the paradigm's scientific robustness, we cannot ignore the social environment of economics when trying to understand the sources of both its success and its failure.

Patinkin's study of anticipations of the General Theory was inspired by rather different motivations. His approach to the sociology of knowledge is purely functional and is intended to enhance the efficiency of economics as a scholarly going concern. the discipline is seen as an organization primarily designed to produce knowledge. Therefore, establishing the priority of scientific discoveries is, first and foremost, in the interest of the efficient operation of the discipline. The historian of economic thought who studies multiple discoveries is entrusted with an important function, to wit:

"and if the reward system of science is to function in a productive manner, its rewards must go to the true discoverers; to those who brought about a cognitive change." (Patinkin 1983, 316)

Second and still according to Patinkin, scientific knowledge is public, and its expansion a cooperative venture; therefore, the scientific community must insist that scientific contributions are brought to its attention as expeditiously as possible. Scholars who fail to publicize their discoveries are rightly doomed to oblivion. Consequently, they must emphasize their most significant discovery as their "central message".

Third, time has value, hence according to Patinkin the first discoverer must be rewarded.

"It is a commonplace that an essential part of the intangible capital of any society is its stock of scientific knowledge; so it is a matter of significance whether an increment to this capital (and to its subsequent yield of fruits) takes place at time $t$ or at time $t+0$, with the degree of significance decreasing with 0. Patinkin 1983, 319)".

These purposes for studying anticipations yield Patinkin's dual criterion: a precise definition of the scientific discovery, and a test whether this discovery was the central message of the relevant publications. The central message is further required to be the common theme of publications and to have appeared in the most effective (prestigious) media of scholarly publications the author could gain access to.

Patinkin is, of course, aware that the more stringent the definition of the scientific discovery, the less likely we are to find multiples (Patinkin 1983, p. 319). He actually conjectures that once his dual criterion is applied to alleged multiple discoveries for want of proper publications, many will turn out to be independent discoveries instead of multiples. Patinkin expresses consolation in the observation 
"that scientific research is less redundant - and, as a corollary, that the individual scientist is more important - than the by-now-familiar long lists of alleged multiple discoveries might lead us to believe". (Patinkin, 320)

This, again, is a very curious application of the efficiency principle. Whereas for technology it has been shown that multiples turned out "to be mutually derivable from one another" (Patinkin 1983, p. 319; citing Elkana 1970, p. 32), for contributions like the General Theory, that is not necessarily true. First of all, as Leland Yeager (1981, p. 283) has pointed out, economics is a science without a corresponding technology, which makes it more difficult to maintain a cumulative growth of knowledge (Cesarano 1983). Second, multiples corroborate. Keynes's German contenders, while in many respects following the same approach as Keynes did, also differed substantially from him in others. In many instances, their criticisms had merit and were later confirmed. In situations like this, the multiplicity of independent discoveries is less a redundancy that amounts to inefficiency (Patinkin 1983, 320) than an indicator of mutual corroboration, pointing to the robustness and soundness of a particular body of theoretical knowledge. Conversely, the absence of multiplicity may raise doubts about the robustness of a particular economic theory.

Keynes undoubtedly provides economists with an excellent opportunity to apply Merton's methodology. We need only look at one rather superficial sign: Great innovators are associated not only with what they have achieved, but also with what they have not accomplished (Merton 1957, p. 299). There is a scarcity of these innovators in economics. But Keynes is such a towering figure in the discipline that we have both Keynesian and post-Keynesian economics.

Hence, an attempt at understanding the sociology of the Keynesian revolution, of which Keynes in both his scholarly efforts and his other achievements forms an essential part, cannot possibly be construed as discounting the importance of the man. Nor must an emphasis on priority a priori be tied to a functional view. As Merton himself was at pains to point out,

"the emphasis on priority is often not confined within functional limits. (...) It becomes stepped up to a dysfunctional extreme far beyond the limits of utility. (Merton 1957, p. 322)"

The ambiguous relationship between an emphasis on priority and the efficiency of knowledge production need not reduce the question of multiple discoveries to insignificance. For one, encouraging multiple discoveries increases the probability that a discovery will be made at all (Merton 1963, pp. 379-380). The corollary of this observation is that reducing redundancy may reduce the likelihood of discoveries, and thus be costly. Hence it follows that redundancies cannot be interpreted as signs of an inefficient organization of science. In economics, the reverse may be closer to the truth.

Multiple research also raises the critical level of acceptance (Merton 1963, p. 380). Competing researchers will scrutinize any alleged discovery, adding to the robustness of research.

This discussion yields two further purposes for studying anticipations in economics. they are, of 
course, different from Patinkin's, but not incompatible:

(1) Explaining conditions under which scientific discoveries can win acceptance helps us understand the sociology of the economics discipline.

(2) That scientific discoveries in economics cannot be readily falsified is not unique with economics. Falsification can take several generations in such hard disciplines as mathematics as well. But if the same scientific discovery, or a very close resemblance, is made by scholars who work independently, perhaps even using completely different paradigms, we can take this as mutual corroboration.

Multiple discoveries provide an excellent opportunity to enquire into the similarities or dissimilarities of sciences (Merton 1963, p. 376) and, one may add, the similarities and dissimilarities between different branches of the same science, such as economics. After all, the Keynesian revolution in economics must be seen as the outcome of a contest between paradigms. In the 1920s, the "race" between the schools of Cambridge, Stockholm, the neo-classical approach, institutionalism, the Austrian school and not least the historical school was still very much an open one. Twenty years later, the Keynesian revolution had for all intents and purposes silenced institutionalist and Austrians alike; the historical school had disappeared altogether, and at one of the new centers of learning, in Cambridge (Mass.) the neo-classical synthesis developed. While these developments are common knowledge today, what has brought them about is not. It is inconceivable to hypothesize that "the internal values and pressures of the discipline" ${ }^{3}$ simply prevailed. The opportunity cost of excluding entire subdisciplines was after all not slight. As David Bloor ${ }^{4}$ has pointed out :

"As well as an external sociology of knowledge, there is also an internal sociology of knowledge... where broad social factors are not involved, narrow ones take over ... By this I mean that the social factors concerned may be ones which derive from the narrowly conceived interest or traditions or routines of the professional community... Much that goes on in science can be plausibly seen as a result of the desire to maintain or increase the importance, status, and scope of the methods and techniques which are the special property of a group... To claim that scientists are educated and socialized into a certain community and address their communications to their peers, is most certainly not... to invoke a trivial mode of social involvement. The claim only appears trivial if it is attended by a shallow or uncertain grasp of the social processes in questions. Properly understood, training, socialization and communication are deep and complex and revealing phenomena".

At the time of the Keynesian revolution, economics had yet to become a professional community. The discipline was much less an integrated science with a common center, a common paradigm, common media of publication, and common social norms than it is now, Patinkin excludes a lot when he asserts that Cambridge was "then (i.e.: in 1936, J.B.) the center of learning in economics" (Patinkin 1983, p. 313). ${ }^{5}$ The point is not unimportant in our context, since Patinkin's dual criterion partly turns on where a particular contribution was published. Each school had its own center of learning, and accorded prestige to publications according to differing criteria among 
which there was little overlap.

Patinkin's emphasis on the media of publication chosen also excludes an important element of academic communication. In Cambridge, especially since Alfred Marshall, the oral tradition has always been strong. Sometimes, the oral tradition was already several decades old by the time ideas appeared in print even to the extent that the printed version might smack of staleness. Similarly, the oral tradition among German economists, notably with respect to Lautenbach, Roepke and Eucken (with the Freiburg School) is legendary. ${ }^{6}$

Let us then look more closely at the German case: the first Point I should like to raise has been well summarized in a review of Patinkin;s study by a leading German scholar of the history of thought: ${ }^{7}$

Trotz der Vieldeutigkeit des Terminus anticipation und den subjektiven Leitlinien, denen PATINKIN naheliegenderweise folgte, befremdet den Leser hierzulande, dass fuer PATINKIN deutsche Vorlaeufer und Wegbereiter offenbar keine Rolle spielen. Dies gilt (...) fuer volle anderthalb Jahrhundert oder, um personale Ansatz- und Wendepunkte auswahlweise zu benennen, von LUDWIG LAMBERT GALL ueber ROBERT KARL RODBERTUS und L. ALBERT HAHN (in seinen juengeren Jahren) bis ROBERT NOELL VON DER NAHMER.

Patinkin is criticized for neglecting a century and a half of German anticipations and steppingstones (sic!). During just the four years preceding the publications of the General Theory, Germany saw the following developments:

1. The implementation of a Keynesian recovery program in 1932 which was based on Keynesian theoretical foundations (Robinson 1972, Roepke 1933). this program remained in effect until approximately 1935.

2. The theoretical and practical works of Wilhelm Lautenbach, which probably led up to the program listed under 1 (Backhaus 1983, Bombach et al. I,II,III 1976-1981, Borchardt 1982, Lautenbach 1952).

3. The reports of the Brauns Kommission, of which both Lautenbach and Roepke were members (Roepke 1931,1933).

4. The prolific writings of Roepke and other members of the Freiburg school (Roepke 1931, a,b, 1932, 1933 a,b, 1936).

5. Independent Keynesian formulations "which owe nothing to Keynes". ${ }^{8}$

6. The contributions of the historical school to a scholarly based program of recovery. Here, Sombart stands out (Backhaus 1983, Sombart 1928, 1932 a,b).

7. The theoretical and programmatic writings of "activists" mostly affiliated with the trade union movement (Woytinsky) and social democratic circles (Neisser, Lederer) which Garvy (1975) has documented.

Several points are well worth mentioning. First, each of these strands of theoretical development was well publicized, not only at home but for the most part also abroad. We must even presume that Keynes himself was largely aware of this literature (Lautenbach, Brauns Kommission, Roepke, Woytinsky, and possibly Sombart, whose works were regularly reviewed in the Economic Journal, of which Keynes was the editor. ${ }^{9}$ Second, the protagonists were eager to 
emphasize their messages in no uncertain terms. For instance, Roepke pursued a publications strategy for which Patinkin (1982) could have been the script. ${ }^{10}$ We might take this multiplicity as an illustration of my earlier thesis that redundancies should not be interpreted as indicators of an inefficient organizations of science.

The second observation is also borne out by the German developments: multiple research raises the critical level of acceptance (Merton 1963, p. 380). In this sense, what happened after 1936 is even more interesting than the developments prior to the publication of the General Theory. First of all, there was an onslaught of critical full-length review articles in the most prestigious German scholarly journals (e.g.: Amonn 1938, Forstmann 1938, Joehr 1937, Kraemer 1937, Lautenbach 1939, Muehlenfels 1938, Peter 1937). Some of these reviews were themselves justly celebrated, such as Amonn's (Bieri 1983). But what is even more striking is the apparent silence from many of Keynes's most prominent German critics. Did they end up agreeing with Keynes? Where was the alternative statement by Hayek or Roepke? what happened to the historical school?

The Paradigmatic Shift.

When Schumpeter emphasized the peculiar vision on which Keynes's General Theory rested, he gave a clue to understanding the leading contenders' (non-) response. To be sure, there were powerful critiques of the Keynesian system outside Germany by, for example, Hayek (1940) or Marget $(1938,40)$. But they largely met with silence . Yet a different development was much more significant. As is well known, Hayek proceeded to write The Road to Serfdom, of which Keynes incidentally approved. Roepke followed up on his article in Harper's Magazine by writing Die Gesellschaftskrisis der Gegenwart. ${ }^{11}$

This paradigmatic shift was not accidental. Indeed Sombart was again first in trying to understand the socioeconomic consequences of the State's assuming the new Keynesian function of economic management. His Deutscher Sozialismus ${ }^{12}$ was a perceptive rendition of the bizarre world of immature ideas and compulsive activism that was about to emerge in Germany. Reading this book is an ordeal. No wonder this work met with incredulity and apprehension everywhere, condemned by friends ${ }^{13}$ and detractors ${ }^{14}$ alike.

Why did the paradigmatic shift come about? The answer was given by Keynes himself, prominently placed in the preface to the (German edition of the) General Theory. ${ }^{15}$

"Nevertheless, the theory of output as a whole, which is much more easily adapted to the condition of a totalitarian state (Totaler Staat), than is the theory of the production and distribution of a given output produced under conditions of free competition and a large measure of laissez-faire. This is one of the reasons which justify my calling my theory a general theory".

Roepke echoes this assessment in a lecture held after the wat in the German town of Wetzlar (Hesse) on the eve of Pentecost 1948:

"Der Nationalsozialismus ist "das bisher einzige Beispiel einer den Keynes'schen Rezepten folgenden konsequenten Politik der "Vollbeschaeftigung" in Friedenszeiten gewesen )...) 
mit welchem Ende und zu welchem politisch-kulturellen Preise(...) brauchen wir nicht mehr zu sagen". (Roepke 1948, p. 11)

Again, the emphasis is on the nexus between State management of the economy and preserving free and democratic institutions. In this context, it was of less importance that, although Keynes's achievement was praised, its dynamic structure was rejected as careless. A more useful question was how to respond to the challenge posed by the emerging Keynesianism. The following quote is from Roepke's letter to Haberler, written immediately after reading the General Theory:

"Wir sind wohl darueber einig, dass Keynes zwar wichtige und sehr ernstzunehmende Dinge sagt, aber sehr leichtfertig mit Dynamik umgeht. Die Frage ist nun, was geschehen soll". (Feb. 23, 1936; Roepke 1976)

Haberler's response was to set to work on Prosperity and Depression, Roepke's was to take up the broader politico-economic implications. Roepke realized that the lasting significance of the General Theory was pertaining to its practice. In view of the economic and political developments, both in theory and in practice. In view of the dramatic political landslide that had simultaneously occurred in central Europe, Roepke's perceptiveness seemed to be a logical research response from one of Germany's most prominent and internationally recognized economists, who found himself driven into Turkish (later Swiss) exile by the same political forces he now tried to understand.

The "New Economics", however emerged unaffected. Twenty years later, economists such as Hayek $^{16}$, Roepke or even Sombart (by then dead), despite their differences, had this in common: their contribution to economics had been disparaged. The profession had been consolidated by excluding heterogenous fields of study and by attempting a synthesis of micro-economics with Keynesianism. This set a new standard of reference for the profession; but only ex post (and for the time being). Patinkin's approach as a tool of scholarly discovery, requires a common set of norms held ex ante in the scientific community.

\section{Conclusion}

With these developments in mind, we must conclude, I think, that Patinkin's approach is unsatisfactory for understanding the sociological issues of the Keynesian revolution in economics. In 1936, the profession lacked a common canon of accepted knowledge, a common oral tradition, and common media of publication with an accepted ranking of importance and prestige.

Although the multiplicity of research prior to 1936 - as long as we do not insist on too narrow a definition of the central message - attests to the robustness of the Keynesian research program, the vigorous criticisms and discussions that met the General Theory in Germany reveal strong contention, again a sign of the robustness of the scientific community. The ensuing professionalization of economics, however, was achieved at a high price. Consolidating the research agenda meant excluding the rich fields of economic sociology and historical economic theory. Recently, this border has been partly relaxed, with the new economic history and public choice staging a precarious comeback. 
Applying Patinkin's approach to spotting the efficiency of the organization of economic inquire is premature, as long as opportunity costs and benefits of alternative organizational and research patterns remain elusive. 


\section{References}

A. Amonn (1938), "Keynes' Allgemeine Theorie des Beschaeftigung", Jahrbuecher fuer Nationaloeko nomie und Statistik, 147 (1-2), pp. 1-27.

Juergen Backhaus, "Economic Theories and Political Interest", Journal of European Economic History, 12 (3), Winter 1983, pp. 661-667

Jürgen Backhaus, Review article, "Anticipations of the General Theory? A Review of Don Patinkin's Homonymus Study. Journal of the History of the Behavioral, Vol. XXII, April 1986, pp. 190-195.

J.W. Balabkins, " A Note on the Soviet Evaluation of J.M. Keynes." Canadian Slavonic papers 12(3), 1970, pp. 343-345

Enrico Barone, Grundzuege der theoretischen Nationaloekenomie. Uebersetzt und mit einem anhang versehen von H. Staehle. Mit einer Einfuehrung von Joseph Alois Schumpeter. 2. durchgesehene Auflage, Berlin, Bonn 1935

David Bloor, "The Strengths of the Strong Program." Philosphy of the Social Sciences 2, 1981, pp. 203-4

Gottfried Bombach et al. (ed.) Der Keynesianismus I, II, III, Heidelberg: Springer, 1976-1981

Knut Borchardt, "Zur Aufarbeitung der Vor- und Fruehgeschichte des Keynesianismus in Deutschland", Jahrbücher für Nationalökonomie und Statistik 197,1982, pp. 359-370

Kurt Braunreuther, "Studie zur Geschichte der buergerlichen konjunkturpolitischen Theorien." Wissenschaftliche Zeitschrift der Humboldt-Universitaet zu Berlin, Gesellschafts- und sprachwissenschaftliche Reihe, 6 (3), 1956-57, pp. 221-231

Filippo Cesarano, "On the Role of the History of Economic Analysis, History of Political Economy, 15.1, 1983, pp. 63-82.

A.W. Coats, "The First Decade of HOPE, 1968-1979", History of Political Economy, 15.3, 1983, pp. 303-320

Yehuda Elkana, "The Conservation of Energy: A Case of Simultaneous Discovery?", Archives Internationales d'Histoire des Sciences, 90-91 January-June 1970, pp. 31-60

Albrecht Forstmann, "Arbeit oder Beschaeftigung? Kritische Betrachtungen zu J.M. Keynes 'Allgemeiner Theorie der Beschaeftigung'." Finanzarchiv N.F. 5, 1938, 375-488

Albrecht Forstmann, Geld und Kredit. Goettingen: Vandenhoeck und Ruprecht 1952

Gottfried Haberler, Prosperity and Depression, Geneva: League of Nations, 1936, English and French, 2nd 1937.

B.J. Hanson, The Stockholm School and the Development of Economic Method, Croom Helm: London, 1982

Friedrich A. Hayek, The Road to Serfdom, London: Kegan Paul, 1944

Michael Hudson, "German economists and the Depression of 1929-1933." History of Political Economy 17 (1), 1985 , pp. $35-50$

Terence Hutchison, Revolutions and Progress of Economic Knowledge. 1978, last chapter

Walter Adolf Joehr, "'Verbrauchsneigung' und ' Liquiditaetsvorliebe':eine Auseinandersetzung mit John Maynard Keynes." Jahrbuecher fuer Nationaloekonomie und Statistik 146 (6), Dec. 1937, 641662

Michał Kalecki, Kapitalizm: Koiuntura i zatrudnienie. Dzieł, tm 1 [Capitalism: business cycles and employment. Works, Vol. I]. Edited by Jerzy Osiatynski. Warsaw: Panstwowe Wydawnictwo Ekonomiczne [State Publishers for Economics] for Polska Akademia Nauk [Polish Academy of Sciences], 1979

John Maynard Keynes, The General Theory of Employment, Interest and Money, London: Harcourt Brace, 1936

John Maynard Keynes, Allgemeine Theorie der Beschäftigung, München: Duncker \& Humblot, 1936 
Carl Kraemer, "John Maynard Keynes ueber Kapitalersparung und- Anlagung: ein Vortrag. "Schmollers Jahrbuch fuer Gesetzgebung, Verwaltung und Volkswirtschaft 61, 1937, pp. 315-328

Carl Kraemer, "Besprechung von Keynes' Allgemeiner Theorie. Währung und Wirtschaft, 1936, 54

Werner Krause und Guenther Rudolph, "Grundlinien des oekonomischen Denkens in Deutschland. (East)Berlin", 1980

Claus-Dieter Krohn, Wirtschaftstheorien als politische Interessen: Die akademische Nationaloekonomie in Deutschland 1918-1933. Frankfurt: Campus, 1981 (= Campus Forschung, Vol 226)

Alfred Kruse, "Theorie der Beschaeftigung." Jahrbuecher fuer Nationaloekonomie und Statistik 146, $1937,72-83$

Alfred Kruse, "Adolf Weber". In : Kruse (ed.), Wirtschaftstheorie und Wirtschaftspolitik. Berlin: Duncker und Humblot 1951

Wilhelm Lautenbach, Zins, Kredit und Produktion. Tübingen: Mohr/Siebeck, 1952.

Alfred Marshall, Principles of Economics I, London: MacMillan 1890.

Robert K. Merton, The Sociology of Science, Chicago: University of Chicago Press, 1973

Robert K. Merton, "Singletons and Multiples in Science", in: Proceedings of the American Philosophical Society 105, number 5 (Oct.1961): pp. 470-486. Reprinted in Robert K. Merton, The Sociology of Science: Theoretical and Empirical Investigations, Chicago: University of Chicago Press, 1973, pp. 343-370.

Robert K. Merton, "Priorities in Scientific Discovery", American Sociogical Review, 22.6, 1957, pp. 635-659. Reprinted in Robert K. Merton, The Sociology of Science: Theoretical and Empirical Investigations, Chicago: University of Chicago Press, 1973, pp. 286-324.

Robert K. Merton, "Resistence to the Systematic Study of Multiple Discoveries in Science", European Journal of Sociology, 4, 1963, pp. 237-282

Antonio Montaner, Review of Patinkin (1982) "anticipations". Kyklos 37, 1984, p. 148

Nonnenbruch, "Der Sozialismus von Herrn Prof. Sombart", Völkerischer Beobachter, 278, 5.X.1934

Michael Oakeshott, "Review of Sombart (1934), Economic Journal,, 1938, p. 537

Bertil Ohlin, "Stockholm and Cambridge: Four Papers on the Monetary and Employment Theory of the 1930's", History of Political Economy 13, 189-255, 1981

Bertil Ohlin, "Stockholm and Cambridge: Four Papers on the Monetary and Employment Theory of the 1930's." Posthumously edited by O. Steiger. History of Political Economy 13 (Summer 1981), pp. 189-255.

Donald Patinkin, Anticipations of the General Theory? And Other Essays on Keynes, Chicago: The University of Chicago Press, 1982

Donald Patinkin, "Multiple Discoveries and the Central Message", American Journal of Sociology, 89.2, 1983, pp. 306-323.

Peter H. (1937), "Zu Keynes' Allgemeiner Theorie der Beschaeftigung, des Zinses und des Geldes", Jahrbuecher fuer Nationaloekonomie und Statistik, 146, pp. 60-83.

Otto Pfleiderer, "Der Keynesianismus." Finanzarchiv N.F. 41 (1), 1983, 108-115

H. Richter-Altschoeffer, Volkswirtschaftliche Theorie der öffentlichen Investitionen: Eine Untersuchung über die theoretische Stellung der öffentlichen Investitionen in der Dynamik der modernen Verkehrswirtschaft, Munich/Leipzig: Duncker \& Humblot, 1936

Joan Robinson, "Michal Kalecki", Cambridge Review 93 (October 22) 1971, pp. 1-3. As reprinted in J. Robinson, Collected Economic Papers, Vol. IV, pp. 87-91.

Wilhelm Roepke, "Wirtschaftsbelebung durch Notverordnung?" Sparkasse 52 (20), October 1932, 381385

Wilhelm Roepke, Die Gesellschaftskrisis der Gegenwart, Erlenbach-Zürich: E. Rentsch, 1943 (4)

Wilhelm Roepke, Die Krise des Kollektivismus, Erlenbach-Zürich: E. Rentsch, 1947. In Dutch: De Crisis 
van het Collectivisme, Comité ter Bestudering van Ordeningsvraagstukken, Vraagstukken van heden en morgen, nr. 1, Voorburg, 1948

Wilhelm Roepke, Die Ordnung der Wirtschaft, Frankfurt am Main: G. Schulte-Bulmke, 1948

Wilhelm Roepke, Wirrnis und Wahrheit (Confusion and Truth). Erlenbach: Rentsch, 1962

Wilhelm Roepke, Briefe 1934-1966: Der innere Kompaß. Erlenbach: Rentsch, 1976

Wilhelm Roepke, Frankfurter Zeitung 1931

Wilhelm Roepke, Krise und Konjunktur, Jena: Gustav Fischer 1932

Wilhelm Roepke, Economic Journal 1922, London, Hodge \& Co. (Festschrift Cassel) 1933

Wilhelm Roepke, Crises and Cycles. London: Hodge \& Co. 1936

Wilhelm Roepke, General Theory, "Totalitarian Prosperity", Harper's Magazine 1939.

Wilhelm Roepke, Social Crisis of Our Time, University of Chicago Press, 1950 (Zürich 1940)

Bertram Schefold, "The General Theory for a Totalitarian State? A Note on Keynes's Preface to the German Edition of 1936", Cambridge Journal of Economics 4, 175-6, 1980

Erich Schneider, "Der Streit um Keynes. Dichtung und Wahrheit in der neueren deutschen Keynes

Diskussion."Jahrbuecher fuer Nationaloekonomie und Statistik 165, 1953, 89-122

Joseph Alois Schumpeter, History of Economic Analysis, New York: Oxford University Press, 1954

Karl-Heinz Schwank, Lord Keynes Theorie:Weder revolutionaer noch wissenschaftlich. Zur Kritik der apologetischen Behauptung von der Renaissance in der modernen buergerlichen politische Oekonomie. Berlin: Dietz 1961

Werner Sombart, Werner Sombart, Deutscher Sozialismus, Berlin: Buchholz und Weisswanger, 1934 1934; in America published as A New social Philosophy by Princeton University Press in 1937

George Stigler Essays in the History of Economics. Chicago:the University of Chicago Press 1965, p. 22

Wolfgang Stüntzel, "Einleitung des Herausgebers". pp. 1-14 in Lautenbach, Wilhelm, Zins, Kredit und Produktion. Tübingen: Mohr/Siebeck, 1952.

Gordon Tullock, The Economics of Inquiry, Durham: Duke University Press, 1966

Leland B. Yeager, "Clark Warburton, 1896-1979", History of Political Economy, 13.2, 1981, pp. 279284

Knut Wicksell, Geldzins und Güterpreise: Eine Studie über den Tauschwert des Geldes bestimmenden Ursachen. Jena: Gustav Fischer, 1898 


\section{NOTES}

1 For an earlier, somewhat similar attempt see Gordon Tullock, The Economics of Inquiry, Durham: Duke University Press, 1966

2 The chapter is entitled:"Concluding Notes on the Social Philosphy Toward which the General Theory Might Lead".

3 This is the working hypthesis of the Chicago approach to the history of thought in economics; the approach is informed by the "marjet of ideas" paradigm. See George Stigler Essays in the History of Economics. Chicago:the University of Chicago Press 1965, p. 22

$4 \quad$ David Bloor, "The Strengths of the Strong Program." Philosphy of the Social Sciences 2, 1981, pp. 203-4; Similary, Terence Hutchison, Revolutions and Progress of Economic Knowledge. 1978, last chapter; see also Coats 1983

5 This does not mean that Cambridge was insignificant. Cambridge was one of the more active centers of higher learning in economics, and everybody was well aware of this fact. In 1936, for example, the editors of the Economic Journal saw a need to have correspondents in Australia, New Zealand, India, Canada, South Africa, France (2), Denmark, Italy, Greece, Sweden, and the United States. The Economic Journal also reprinted the contents of current economics journals. Here, the British publications occupy less than 20 percent of the space allocated, and the journals published in a language other than English (notably German, French, and italian) take up more than 50 percent.

$6 \quad$ See Stuetzel in Lautenbach 1952, "Editor's Introduction"

7 Antonio Montaner, Review of Patinkin (1982) "anticipations". Kyklos 37, 1984, p. 148

8 Schumpeter 1954, p. 1174 refers to Foehl 1974; but even more notable is ritcher-Altschoeffer 1936

9 Keynes is said to have been a very diligent editor, he can therefore not have overlooked Roepke's discussion of German business cycle policies and its theoretical considerations. the "Brauns Kommission" was similar to the MacMillan Commission

10 Roepke published his results in Frankfurter Zeitung 1931, Krise und Konjunktur, Jena: Gustav Fischer 1932, Economic Journal 1922, London, Hodge \& Co. (Festschrift Cassel) 1933, Crises and Cycles. London: Hodge \& Co. 1936, and after the appearance of the General Theory, "Totalitarian Prosperity", Harper's Magazine 1939. At the same time, Roepke's close friend Haberler published Prosperity and Depression. Geneva 1937 (English and French), 2nd 1937, would summarily refer to as consistent with his own approach (e.g.: letter, March 14, 1942; published in Roepke 1976)

11 Zurich 1940, published in America as the Social Crisis of Our time in 1950 by the University of Chicago Press

12 1934;in America published as A New social Philosophy by Princeton University Press in 1937

13 Economic Journal "it is impossible not to regret that Sombart should have brought himself to write 
most of this book", Michael Oakeshott, 1938, p. 537

$14 \quad$ Der Voelkische Beobachter Oct. 10, 1934

15 I am quoting from Schefold's (1980, p. 175) version, which is more complete than the version printed in the Collected Works, Vol.VII, pp. xxvi-xxvii. For an earlier translation of J.M. Balabkins, " A Note on the Soviet Evaluation of J.M. Keynes." Canadian Slavonic papers 12(3), 1970, pp. 343-345

16 His winning the Nobel Prize notwithstanding. The case of the Austrian school is interesting insofar as it has managed to resurface in some quarters. Still, it can hardly be said to have won acceptance by the mainstream, or in the "center". 